\title{
PARTICULARITY OF BREEDING AND PERSPECTIVES ON THE USE OF MOLECULAR GENETIC METHODS IN FLAX (Linum usitatissimum L.) GENETICS AND BREEDING RESEARCH (review)
}

\section{I.V. USHCHAPOVSKII ${ }^{1}$, V.V. LEMESH ${ }^{2}$, M.V. BOGDANOVA ${ }^{2}$, E.V. GUZENKO ${ }^{2}$}

${ }^{1}$ All-Russian Research Institute for Mechanization of Flax Cultivation, Federal Agency of Scientific Organizations, 17/56, Komsomol'skii prosp., Tver', 170041 Russia, e-mail vniptiml@mail.ru;

2Institute of Genetics and Cytology of NAS of Belarus, 27, ul. Akademicheskaya, Minsk, 220072 Republic of Belarus, e-mail V.Lemesh@igc.bas-net.by, mw.bogdanova@gmail.com, E.Guzenko@igc.bas-net.by Received November 27, 2015

\section{Abstract}

Breeding and genetic researches of flax (Linum usitatissimum L.) started more than 100 years ago, but their relevance does not decrease. More than 200 cultivars of this culture are offered in the international seed market for oil and fiber production with yearly amount of the harvested area about one million hectares and 0.3 million hectares, respectively. Different agro-climatic conditions in the countries, in which flax is being cultivated, and the progress in technologies of processing and new ways of application of products made of the fibers and other parts of the flax plant determine the necessity to accelerate breeding process. Now duration of breeding work for creating a new variety is up to 10-15 years. The dominating method for flax breeding is intraspecific hybridization with the subsequent selections. Basic part of breeding work is ecological trials and intensive using in the crossing the best new cultivars, old popular varieties («kriazhee»), local samples and breeding forms (S.N. Kutuzova et al., 2010; A. Diedrechsen et al., 2013). Prebreeding work focuses on the overcoming of limits of traditional hybridization methods by using some peculiarities of combinative variability (L.N. Pavlova, 2010). Recombination induction can be achieved by using the stress conditions for flax plant (hybrid) growing (A.A. Zhuchenko Jr. et al., 2009). Physical ( $\gamma$-radiation) and chemical (Nnitrosomethylurea, ethyleneimine, dimethyl sulfate) mutagens considerably raise an output of mutant forms which possess economically valuable traits (M.I. Loginov et al., 2005; I.V. Uschapovsky, 2013). The article examines the examples of the use of cell and tissue culture techniques that extend somaclonal variation and allow to produce flax lines with desirable properties, including disease resistance (fusariosis, anthracnose) (V.A. Lyakh et al., 2008; N.V. Proletova et al., 2010). The review describes DNA marking technology which allows us to group genetic material of flax according to its genetic proximity and to optimize matching the genotypes to crossbreeding in view of saving the maximum genetic diversity (Y.B. Fu et al., 2003; V.A. Lemesh et al., 2006). SSR analysis is examined as the perspective direction for genetic identification of flax lines and cultivars (V.A. Lemesh et al., 2013), identifications of inter- and intraspecific genetic linkages (J. Vromans, 2006), possible linkages between molecular markers and economically important traits (V.A. Lemesh et al., 2012) and establishments of linkages groups between marker pairs (S. Cloutier, 2012). The directions of possible integration of traditional breeding methods and methods of molecular biology for creation of new flax cultivars with the set of the parameters of economically important traits are considered.

Keywords: fiber flax, linseed, breeding, hybridization, selection, mutagenesis, tissue culture, genetic variability, primers, markers, SSR, PCR

Common flax (Linum usitatissimum L.), because of the unique properties of its fiber and oil, is being used since the dawn of human civilization and still is of interest. Flax is an annual plant with a short growing period (80-120 days), a small number of agronomic and morphological traits, low rate of reproduction and small flower in which pollination, as a rule, occurs before the opening. Despite the fact that the crop is studied deeply enough, its phylogenesis, ontogenesis, genetic control and the inheritance of the traits remain topical for researchers [1-4].

Flax domestication and breeding resulted in the two types of pure-line varieties grown for fibers taken from the stems (fiber flax varieties) and for lin- 
seed oil and other components of the seeds (oilseed varieties). To date, more than 250 flax varieties are recorded in the world [5]. FAO UN reports the flax crop area remains relatively constant in recent years accounting for over 2.3 million hectares for oilseed flax and over 0.3 million hectares for fiber flax [6]. Since interest in the flax production is growing due to its use in various industries and the development of the doctrine of environmentally friendly economy, the area of flax crops will expand and the flax breeding will be increasingly important. Note, two flax morphotypes, due to intraspecific similarity, should be considered as a whole in the genetic studies and breeding.

The purpose of our review is to generalize the results and give an outlook on the prospects of molecular genetic techniques for the flax study and breeding.

Historical overview of flax breeding. As a common practice, flax breeding started in Holland and in Russia since the beginning of the XX century. First it was an experimental individual selection within local flax populations [79]. Since then, the flax breeding was largely based on a combination of simple and complex crosses followed by pure line selection [10, 11]. Practical experience of the breeder and a large number of parental forms checked under various conditions were essential to create the crop varieties [12]. In flax, the difficulties are mainly related to the fact that the genetics of this crop is poorly understood, a set of Mendelian genes used is small, the major valuable traits are controlled by QTLs, and different national research programs are not well coordinated.

Retrospectively, a scale of flax breeding methods is as follows (Fig.).

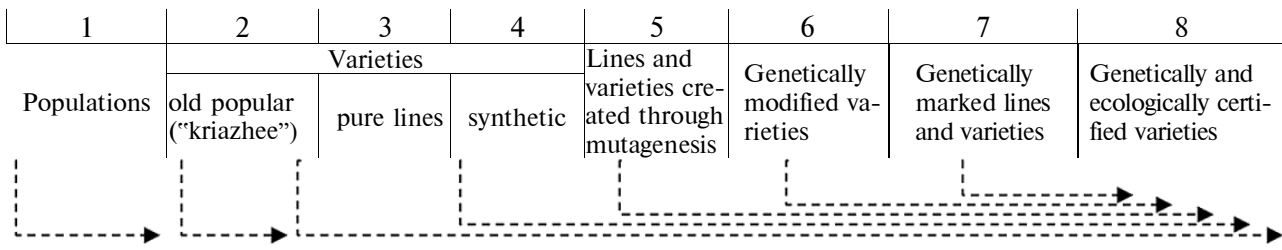

Evolution in flax (Linum usitatissimum L.) breeding techniques and the types of varieties created: 1 unconscious selection (from the introduction in the VII-V centuries BC); 2 - massive selection (XIII-XIX centuries); 3 - individual selection (since the beginning of the XX century); 4 - hybridization based on meiotic recombination (since 1920); 5 - induced mutagenesis (since 1960); 6 - cell culture technique and genetic transformation (since 1980); 7 - molecular markers (since 1990); 8 an integrated approach (forecasted from the 2020s).

The flax cultivation started with unconscious selection by man of plants for fiber and food use. It is believed to occur in the heyday of the Ancient Egypt civilization (7-5 thousand years ago), but earlier dates (10-30 thousand years ago) are supposed for flax introduction in the Colchis territory [13, 14]. Resulting flax populations were little influenced by selective factors during thousands of years of evolution and still can be found in the territories of cultivated flax origin, presenting a valuable material for its study. The world's flax collections preserve specimens of most these populations [4, 15-18]. Russian old landraces of flax (so-called kriazhee"), the polymorphic local populations known in the major regions of flax cultivation in Russia since XII-XIII centuries, are a classic example of mass selection from natural flax populations. These landraces produced more fiber of better quality in the place of origin, but did not possess the genetic stability and uniformity [1]. The first research schools engaged in flax breeding appeared at the end of the XIX century in Western Europe and Russia. For the first time, pure line flax varieties were obtained based on individual selection and crosses [12]. Flax breeding is mainly focused on productivity (straw output, fiber, seed and oil yields, fiber content in the stem), quality (fineness and breaking load of fiber, fatty acid composition of the oil, the content of bioactive substances in the seeds), resistance to fungal diseases, edaphic and climatic factors, ontogeny peculiarities (the length of vegetation period and the transi- 
tion periods between ontogenetic phases, a synchronization of generative and vegetative growth). A high yield of fiber or oil, disease resistance and lodging resistance remain the priorities for nearly a century.

Currently, from 300 thousand to 1 million USD and more than 10 years are required to create a flax variety [19]. The most successful breeding groups manage to offer up to three varieties annually, but practical introduction of the novelties faces with many economic and organizational difficulties [20]. Stable varieties with acceptable economic value and agronomic characters (L-1120, Orshanskii 2, Belinka, Mogilevskii, etc.) can be cultivated for decades. However, intensive agriculture necessitates varieties which perform stable yielding, high quality $[21,22]$ and possess new traits or their combinations (e.g., dual purpose or winter flax).

Combination selection and sources of genetic diversity. Genetic (meiotic) recombination remains the most effective in breeding oilseed and fiber flax and involves simple hybridization, backcrossing, pollination of three or more varieties, sequential crossing. The vast majority of modern flax varieties have been created due to genetic (meiotic) recombination [21-24]. The identification of transgressive makes it possible to form a selection fund on the parameters of efficiency and quality of flax fiber [25]. However, the in-depth study of the flax recombination system is neglected [26].

Important sources of agronomic traits are working, national and international (under the auspices of FAO) flax collections [15, 17, 27-29], numbering more than 25 thousand items in total. From 1930s to 2000s, the flax breeding resulted in a narrowed genetic diversity, leading to increased undesirable correlations between productivity, earliness and quality [30]. It should be recognized that the genetic study of the flax collections is not deep enough, and scientific cooperation of the major collection holders is rare, while current characterization of the gene pool, prevention of sample duplication, reliable preservation and effective use of the resources require a correct assessment of genetic diversity $[16,31,32]$. Local landraces and forms resulted from a long natural and artificial selection are considered the "Golden Fund", as they are better suited to locale conditions, including the length of growing season [27]. Knowledge of the basic features of local varieties allows establishing their phylogenetic relationships and geographic distribution of alleles (gene geography).

Among the molecular genetic methods [33], we note the molecular marking. That is particularly effective for species which, like flax, are characterized by weak intravarietal differences. Molecular techniques revealed that in modern flax varieties the frequency of rare and unique alleles of microsatellite loci decreased while that of the fixed recessive RAPD (random amplification of polymorphic DNA) loci increased, indicating a narrowing of genetic variation [34]. SSR (simple sequence repeats) analysis is effective to detect unique loci that increase the genetic diversity. Based on the evaluation of microsatellite loci polymorphism, the valuable source populations with rare and unique alleles have been isolated among fiber and oilseed flax varieties and Belarusian landraces [35].

Induced mutagenesis. $\gamma$-Irradiation (200-900 Gy) of flax seed allows to get the progeny with positively altered valuable traits [36], and chemical mutagens (N-nitrosomethylurea, ethyleneimine, dimethyl sulfate), stimulating genetic variability, lead to an increased (over $30 \%$ ) output of mutant families in the progeny of treated plants [37]. Stressor (herbicide) enhances the effect of ethyl methane sulfonate (EMS) in flax [38]. However, mutational variability is not used wide enough. For more than half a century only $3 \%$ of the flax varieties were developed using radiation and chemical mutagenesis [39]. An example of successful experimental mutagenesis in oilseed flax breeding is a commercial variety Solin with modified fatty acid composition. It is shown that the low $\alpha-$ 
linolenic acid in flax is control by two independent recessive gene loci. EMSinduced mutants altered in two these genes were found in $\mathbf{M}_{2}$ [40]. By selfpollination of $\mathrm{M}_{2}$ plants a low-linolenic-acid line was developed with less than 2 $\% \alpha$-linolenic acid compared to $49 \%$ level in the wild-type parent variety McGregor. EMS was also used to isolate two mutants [41] characterized by $30 \%$ linolenic acid content. Their recombination generated plants with less than $2 \%$ $\alpha$-linolenic acid, and a sharp reduction in the linolenic acid content in seeds was not accompanied by its change in leaves [42]. There is a large collection of oilseed flax $\gamma$-ray- and EMS-induced mutations in the genes affecting growth, flowering, etc. [43].

A codominant DNA marker MutFad3, able to detect a mutant allele of gene $\mathrm{fad} 3 \mathrm{~B}$ encoding $\omega 3 / \Delta 15$-desaturase in flax has been designed the Institute of Genetics and Cytology (Belarus) to reveal genotypes with a decreased $\alpha$ linolenic acid content in the seed oil [44].

Cell and tissue culture. Doubled haploids, transformants and somatic mutations can be involved in breeding via in vitro culture.

Interestingly, flax embryos were among the first embryoids cultured in vitro [45, 46], and initiation of growing point in the flax hypocotyl explants was first reported in 1946 [47]. In 1970s there were publications on the effect of various components of culture media on flax morphogenesis in in vitro culture [48, 49]. Ability of flax hypocotyl pieces to form shoots, developing into full plants, and rhizogenesis in calluses derived from protoplasts were discovered in 1976 [50]. The same researchers found the dependence of in vitro regeneration on the genotype of explants [50].

First explanation of differences between in situ and in vitro processes was also experimentally obtained on flax. In early studies, flax immature and mature zygotic embryos were used to induce somatic embryogenesis [51]. Then somatic embryos were derived from hypocotyl segments of seed flax, germinated in vitro [52], and form protoplasts of L. alpinum L. [53]. A number of factors (source of carbon, total nitrogen content, free sterol, the ratio of calcium to zeatin) has been reported to influence somatic in vitro embryogenesis in flax hypocotil explants [54]. Various agents (6-benzylaminopurine, etc.) are tried to stimulate callus growth and organogenesis in vitro from hypocotil tissue [55]. Plants regenerated from hypocotyl had changed valuable traits, including improved resistance to fusarium [56]. Study of callus formation and regeneration showed different genetic mechanisms underlying these processes [57].

Haploid and dihaploid lines were regenerated from anther and microspore cultures in fiber flax [58, 59] and crown flax [60]. Currently, there are a significant number of domestic lines resistant to fusarium and anthracnose produced due to in vitro selection on the growth media containing toxins $[61,62)$. In vitro selection for resistance to $\mathrm{Al}$ and temperature is quite effective in flax $[63,64]$. Obviously, somaclonal variation extends the opportunities of practical breeding. Additionally, in vitro experiments give deeper understanding of the fundamentals of cell metabolism.

Transgenesis in flax. The first successful Agrobacterium tumefaciens-mediated genetic transformation of flax with the use of strain carrying a non-oncogenic Ti plasmid-derived vector containing a chimaeric $n p t-I I$ gene and a wild type nopaline synthase gene occurred in 1987 [65]. In 1988, the transformation of flax via other pathogenic bacteria, A. rhizogenes, was first reported [66]. In the same year, data on genetically modified linseed flax resistant to glyphosate were published [67, 68]. These plants, after the hypocotyl explant transformation, acquired an insertion of gene encoding 5-enolpyruvylshikimate3-phosphate (EPSP) synthase. The same authors also developed the transgenic 
flax plants resistant to herbicide chlorsulfuron [68]. Laboratory tests and field trials at elevated herbicidal load showed the ability of the plant progeny to produce the forms that combined high yield and herbicide resistance [69, 70]. There was an attempt to transfer the pat gene encoding phosphinotricine-N-acetyltransferase which confers resistance to the nonselective herbicide glufosinate, however, field trials were not successful [71]. The $\beta$-1,3-glucanase gene from potato was introduced in flax to improve tolerance to Fusarium oxysporum and $F$. culmorum. The resistance to Fusarium in the resulting transgenic plants was 3-times higher as compared to unmodified forms [72].

Appearance of escapes, the "false transformants" which have adapted to antibiotic- or herbicide-containing selective medium in the absence of inserted foreign DNA in their genome, is a side effects at transgenesis. In vitro conditions could be considered as stress, resulting in enhanced rate and range of genetic variability (poly- and aneuploidy, point mutations, transposition of mobile elements, somatic crossing-over, etc.). Due to somaclonal variations in flax in vitro culture, it was possible to derive forms resistant to extreme environmental factors [73], salinity [74], stress [75], the herbicide chlorsulfuron [76], and fungal diseases $[59$

False transformants, surviving despite the stress factors, apparently possess higher physiological adaptiveness, can extend the spectrum of genetic variation and, therefore, be useful to create forms with a valuable combination of traits. Based on false transformants, four fiber flax populations were first created in the Institute of Genetics and Cytology (Belarus). Certain plant groups significantly exceeded the initial variety in the number of bundles on a cut and the number of elementary fibers per slice (the latter by $12.2 \%$ ), indicating a welldeveloped fibrous tissue and, consequently, higher quantitative and qualitative characteristics of the fiber. Two-year field trials of false transformant-based populations of fiber flax showed a significant excess in total plant height, a technical length, and the number of seed capsules and seeds compared to those of the initial varieties [77].

Protein markers. Hampering flax breeding, despite a success of hybridization and selection, is due to the fact that the biological limits for major improved valuable traits have been almost reached. Therefore, the assessment of genetically determined characteristics, their comparison and phased monitoring of breeding process necessitate a transition to molecular level. For this end, different marker system can be used, including DNA and protein markers [78-81].

Identification and certification of flax varieties and biotypes based on the storage protein polymorphism are not widely used. There are two types of flax seed proteins, the $2 \mathrm{~S}$ albumins (conlinins) encoded by two independent loci Cnll and $C n l 2$ [82], and 11S globulins [83]. The patterns of storage proteins (and total seed proteins) in Russian [84, 85] and foreign [86] flax varieties differed slightly with different methods of extraction and electrophoresis, so their use in genetics, phylogenetics, taxonomy, breeding and seed production remains questionable.

Isozymes may also be the biochemical markers. It is shown that in fiber flax cultivars there are two isoforms of 6-phosphogluconate dehydrogenase, two isoforms of acid phosphatase, and four patterns of aspartate amine transferase isozymes due to the lack of one or more isoforms [79]. However, the homogeneity found in majority of the samples does not allow to use these isoenzymes for intraspecific and varietal differentiation. Nevertheless, the horizontal electrophoresis showed high genetic diversity in three enzyme systems (PGD - 6-phosphogluconate dehydrogenase, GPI - glucose phosphate isomerase and MDH malate dehydrogenase) both between the varieties of different types (fiber flaxes, oilseed flaxes and landraces), and within each sample [87]. 
DNA markers. DNA markers facilitate differentiation of both individuals and taxons. Marker assisted breeding (or marker assisted selection), when the DNA markers tightly-linked to target loci are used, greatly improves the breeding programs.

It should be noted that the analysis of structure and function of flax genome is limited by insufficient knowledge of its karyotype. The difficulties in kariological studies started more than half a century ago arise from a small size of the chromosomes, complicated chromosome identification and cytological study of meiosis. In early publications the chromosome counts, reported for L. usitatissimum, differed $(2 n=30$ and $2 n=32)$ [88-91], and only recent investigations confirmed that the diploid number of chromosomes in L. usitatissimum is 30 [92]. Differential staining pattern of flax chromosomes visualized by fluorescence in situ hybridization with DAPI (4',6-diamidino-2-phenylindole) was similar to $\mathrm{C}$-staining. The largest C/DAPI bands are located mainly in the precentromeric regions, while medium and small C/DAPI bands are located in the telomeric and intercalary regions. In the flax genome there are one or two basic $26 \mathrm{~S}$ rDNA loci, co-localized with 5S rDNA loci, and one to three individual 5S rDNA loci [92].

Flax genome consists of $\sim 35 \%$ highly repetitive nucleotide sequences, $\sim 15 \%$ moderately repetitive nucleotide sequences and $\sim 50 \%$ low-copy sequences [93]. Early cytogenetic study revealed two nucleolar organizer regions with rRNA genes organized in tandem repeats $8.6 \mathrm{~kb}$ in length, encoding $45 \mathrm{~S}$ rRNA and spacer DNA. 45S rRNA is a precursor of 25-, 5,8S and $18 \mathrm{~S}$ rRNAs [94]. The 5S rRNA loci are evenly distributed along the flax chromosomes as a tandem repeats 350-370 bp in length, consisting of transcription units (120 bp) and spacers $(230 \mathrm{bp})$ [90]. The multigene 5S rRNA family $(\sim 117,000$ copies per diploid genome) accounts for about $3 \%$ of the genome [95], whereas in Arabidopsis the 5S rRNA genes comprise only $0.7 \%$ of the genome [96].

According to the earlier data, flax genome ranged from $\mathrm{C}=538$ million bp to $\mathrm{C}=685$ million $\mathrm{bp}$ in size, although the reassociation kinetics indicated $\mathrm{C}=350$ million bp [93, 97]. As to recent estimates, the genome of oilseed flax variety CDC Bethune is $\sim 373$ million bp in size [98]. This genome was sequenced with the use of WGS (whole genome shotgun) method [98]. The sequencing resulted in 116,602 contigs (a total length of $\sim 302$ million bp) assembled in 88,384 scaffolds $(\sim 318$ million bp in size) that made $\sim 81 \%$ of the flax genome. The remaining 70 million bp were the gaps within and between scaffolds. To date, after correction the total length of assembled scaffolds makes 271 million $\mathrm{bp}$. The estimated size of flax chromosomes ranges from 15.1 to 32.8 million bp [99].

In 2011 [100], the first flax genetic map was constructed which included 24 linkage groups with 113 markers, covering $~ 833.8 \mathrm{cM}$. QTL analysis revealed two main QTL loci for linoleic acid (LIO, QLio.crc-LG7, QLio.crc-LG16), two main QTL loci for linolenic acid (LIN, QLin.crc-LG7, QLin.crc-LG16), two main QTL loci for iodine value (IOD, QIod.crc-LG7, QIod.crc-LG16) and one main QTL locus for palmitic acid (PAL, QPal.crc-LG9). Mutant allele fad $3 A$ mapped to the chromosomal segment inherited from the parent SP2047 form, underlies the QTL on linkage group 7 and was positively associated with high LIO level but negatively associated with LIN and IOD values. Physical map of the flax genome [101] contains 416 contigs averaged $\sim 368$ million bp in length. Of known fractions of the genome $(54.9 \%), 20.7 \%$ are dispersed repeats, including LTR-Copia elements (3.4\%), LTR-Gypsy elements (1.8\%), LINEs and SINEs $(0.4 \%)$, unclassified LTR elements, DNA transposons $(0.4 \%)$, ribosomal DNA $(13.8 \%)$ and microsatellites $(0.2 \%)$. The coding regions occupy $26.8 \%$ of 
the flax genome, and functions of $45.1 \%$ are unknown.

Integration of genetic and physical maps [102] showed that the haploid chromosome number in L. usitatissimum corresponds to 15 linkage groups. In sum, the consensus genetic map length is $1551 \mathrm{cM}$. A total of 670 markers are located on physical map within 204 of 416 contigs, covering 274 million bp, or $74 \%$ of the flax genome (370 million bp).

RAPD-analysis revealed the genetic diversity within and between varieties of flax and landraces [80], and the genetic diversity and geographical distribution of Canadian flax that facilitated the understanding of flax domestication [103]. It is shown that the flax varieties are very similar in genetic markers and constitute a homogeneous group, whereas oilseed flax forms several groups with nine landraces. It is also noted that in Canada, flax breeding has led to greater loss of genetic diversity than in the US. These findings concern most loci involved in the Canadian breeding programs. Geographically distant samples showed $84.2 \%$ variability between the countries with $15.8 \%$ variability within one country. The samples from East Asia and Europe had the highest genetic diversity, and those from Africa and India were more genetically homogeneous [103, 104].

Experts, when testing flax varieties according to the DUS (distinctness, uniformity, stability) criteria, noted that the morphological variability of new varieties decreased significantly [104], indicating their narrow genetic basis. AFLP (amplified length fragment polymorphism) analysis of a large number of samples revealed inter- and intragroup genetic diversity of fiber flax and oilseed flax under the growth conditions. Although the analysis failed to distribute the flax varieties in clusters, fiber flax population was found to be a subgroup of the oilseed flax population. This confirms separation of fiber flax from oilseed flax due to recent breeding for fiber quality, and, in turn, is consistent with the hypothesis of the origin of fiber flax from oilseed flax [78, 105]. Based on the submitted hypothesis, older flax varieties should have more similarities with the varieties of oilseed flax than modern varieties.

Due to 1306 SSR markers described to date, flax plants occupy a prominent position among other major crops [106]. According to various publications, trinucleotide repeats predominate among flax microsatellites [107-111]. However, these data may be misleading, since ESTs (expressed sequence tags) characterized by trinucleotide repeats were used in most studies to design corresponding primers. In flax, trinucleotide SSRs are the most common, but dinucleotide SSRs are more polymorphic [102] that is in line with the data for some other crops. It is shown [112], that a trinucleotide repeat AGC-GCA-CAG is most abundant in taro, ginseng, tangerine, millet, ginger, persimmon, lawn grass and foxtail Italian, AGG-GGA-GAG prevails in Chinese cabbage, Eleusine coracana, radish and sesame, a dinucleotide repeat AG-GA is the most frequent in Chinese cabbage, Eleusine coracana, cuckoo tears, railings, amaranth, sesame, radish, persimmon, apricot, and AC-CA is characteristic of sesame, mandarin, ginger, taro. In flax, trinucleotide GAA-AAG-AGA and dinucleotide AT-TA motifs were the most common, indicating the unique composition of its genome [102].

Trinucleotides are common for EST-derived SSR markers $(68.7 \%)$ rather than for those BES (BAC-end sequences)-derived (54.6\%) [102], probably due to suppression of non-trimeric SSRs in the coding regions which can change reading frames. Polymorphism positively correlates with the number of repeats per locus and the total length of the locus. In this, BES SSR markers can reveal significantly higher polymorphism $(58 \%$, PIC $=0.39)$ compared to EST SSR markers $(42 \%, \mathrm{PIC}=0.34)$. Interestingly, polymorphism in flax varieties, even at $42 \%$ effectiveness of EST SSR markers, is higher than that of wheat, barley, 
soybean and cotton [106, 108, 113-115]. However, the polymorphism level may vary substantially depending on the number of investigated genotypes and their genetic diversity (Table).

SSR markers described in flax (Linum usitatissimum L.)

\begin{tabular}{|c|c|c|c|c|c|c|c|}
\hline \multirow{3}{*}{$\begin{array}{l}\text { Source of } \\
\text { SSR }^{1}\end{array}$} & \multicolumn{5}{|c|}{ Number of } & \multirow{3}{*}{$\mathrm{PIC}^{2}$ (limits) } & \multirow{3}{*}{ Authors } \\
\hline & \multirow{2}{*}{$\begin{array}{l}\text { geno- } \\
\text { types }\end{array}$} & \multirow{2}{*}{$\begin{array}{l}\text { polymorphic } \\
\text { primer pairs }\end{array}$} & \multicolumn{2}{|c|}{$\begin{array}{r}\text { loci } \\
\end{array}$} & \multirow{2}{*}{$\begin{array}{l}\text { alleles } \\
\text { per locus }\end{array}$} & & \\
\hline & & & in total & $\begin{array}{l}\text { per primer } \\
\text { pair }\end{array}$ & & & \\
\hline Genome & 8 & 10 & - & - & $3.7(2-8)$ & $0.60(0.25-1.0)$ & I. Wiesner et al. (2001) \\
\hline Genome & 93 & 23 & 28 & 1,22 & $3.3(2-10)$ & $0.33(0.02-0.73)$ & C. Roose-Amsaleg et al. (2006) \\
\hline ESTs & 23 & 248 & 275 & 1,11 & $2.3(2-7)$ & $0.35(0.08-0.82)$ & S. Cloutier et al. (2009) \\
\hline Genome & 60 & 60 & 66 & 1,10 & $3.0(2-8)$ & $0.39(0.06-0.87)$ & B.J. Soto-Cerda et al. (2011) \\
\hline Genome & 8 & 35 & 37 & 1,06 & $3.5(2-6)$ & $0.60(0.23-0.84)$ & X. Deng et al. (2010) \\
\hline ESTs & 61 & 23 & 23 & 1,00 & $2.3(2-4)$ & $0.38(0.08-0.55)$ & B.J. Soto-Cerda et al. (2011) \\
\hline Genome & 8 & 38 & 38 & 1,00 & $3.4(2-12)$ & $0.43(0.20-0.88)$ & X. Deng et al. (2011) \\
\hline Genome & 27 & 9 & - & - & - & - & S.M. Kale et al. (2011) \\
\hline Genome & 19 & 42 & 42 & 1,00 & $3.3(2-8)$ & $0.47(0.10-0.86)$ & C.L. Bickel et al. (2011) \\
\hline ESTs & 16 & 145 & 149 & 1,03 & $2.4(2-6)$ & $0.34(0.12-0.70)$ & S. Cloutier et al. (2012) \\
\hline BESs & 16 & 673 & 720 & 1,07 & $2.8(2-9)$ & $0.39(0.12-0.85)$ & S. Cloutier et al. (2012) \\
\hline In total & & 1306 & 1400 & 1,07 & & & \\
\hline
\end{tabular}

Trinucleotides are common for EST-derived SSR markers (68.7\%) rather than for those BES (BAC-end sequences)-derived (54.6\%) [102], probably due to suppression of non-trimeric SSRs in the coding regions which can change reading frames. Polymorphism positively correlates with the number of repeats per locus and the total length of the locus. In this, BES SSR markers can reveal significantly higher polymorphism $(58 \%$, PIC $=0.39)$ compared to EST SSR markers $(42 \%, \mathrm{PIC}=0.34)$. Interestingly, polymorphism in flax varieties, even at $42 \%$ effectiveness of EST SSR markers, is higher than that of wheat, barley, soybean and cotton [106, 108, 113-115]. However, the polymorphism level may vary substantially depending on the number of investigated genotypes and their genetic diversity (Table).

Integration of molecular and traditional approaches. Breeding programs necessitate estimation of genetic variability occurred in present and primitive old cultivars of flax naturally or due to recombination and mutagenesis. Molecular genetic methods are effective to identify lines and varieties, inter- and intraspecific relationships, to find markers associated to quantitative traits, and to assign markers to linkage groups. Cluster analysis, based on grouping forms according to their genetic proximity, makes it possible to optimize hybridization in order to maintain the maximum genetic diversity of flax breeding material.

Molecular and traditional breeding methods, when integrated, are also important in the certification of varieties (for copyright, control of purity and matching to reference standards). Presently, use of molecular markers in DUS testing in the countries of UPOV (International Union for the Protection of New Varieties of Plants) remains debatable for technical (choice of methods of molecular marking) and legal aspects. UPOV's official view is summarized in a number of documents relating to the development of appropriate methodological approaches. Recommended molecular markers should be associated to traditional traits of the variety and convenient to determine disease resistance, genetic modifications (e.g., tolerance to herbicides), etc. Molecular markers are the most helpful $\mathrm{n}$ species with weak intravarietal differences, such as flax and rape.

DNA-markers have several advantages. They are high-resolution and, therefore, enable more precise revealing differences between the specimens. Molecular methods are applicable at all stages of plant development, being especially indispensable, when traditional approaches do not reliably allow distinguishing the samples. DNA analysis, along with pedigree method and information about 
the key valuable polygenic traits of a variety give the most characteristic features for its description and certification. It is also important that modern technologies allow development of the DNA markers to assess the conformity of new varieties to standard criteria under DUS testing. Based on polymorphism, a panel of 11 pairs of SSR primers for genotyping flaxes poorly distinguishable or indistinguishable morphologically and a system for reliable molecular genetic certification have been developed in the Institute of Genetics and Cytology (Belarus) [116, 117]. The allele Lu8207 which can serve as SSR marker of low linolenic oilseed flax was revealed by microsatellite analysis of low and high linolenic varieties carried out in the Institute of Genetics and Cytology (Belarus) [43].

Thus, step-by-step algorithm for flax breeding and genetic improvement by combination of traditional and molecular techniques involves 1) screening potential parental forms for commercially valuable traits under different environmental conditions; 2) molecular genetic analysis of the sources of valuable traits found; 3) hybridization and selection based on bioinformatic models (QTL analysis, cluster analysis, etc.); 4) DUS UPOV testing of the derived lines; 5) national or international registration of a new variety based on its genetically fixed characteristics with a Plant Variety Protection Certificate

\section{REFEREN CES}

1. S i n s k y a E.N. V sbornike: Sbornik rabot po biologii razvitiya i fiziologii l'na [In: Collected works on developmental biology and physiology of flax]. Moscow, 1954: 5-45 (in Russ.).

2. S i z o v I.A. Len [Flax]. Moscow-Leningrad, 1955 (in Russ.).

3. Gi 11 K.S. Linseed. Indian Council of Agricultural Research, New Dehli, 1987.

4. Kutu zova S.N. V sbornike: Genetika kul'turnykh rastenii (len, kartofel', morkov', zelenye kul'tury, gladiolus, yablonya, lyutserna) [In: Genetics of cultivated plants (flax, potatoes, carrots, green culture, gladiolus, apple, alfalfa)]. St. Petersburg, 1998: 6-52 (in Russ.).

5. Gosudarstvennyi reestr selektsionnykh dostizhenii, dopushchennykh $k$ ispol'zovaniyu. Tom 1. Sorta rastenii (ofitsial'noe izdanie) [RF State Register of breeding achievements approved for use. V. 1. Plant varieties]. Moscow, 2014 (in Russ.).

6. Food and Agriculture Organization of the United Nations. FAOSTAT. Available http://fenix.fao.org/faostat/beta/en/\#data/QC. No date.

7. R e n a rd K.G. Len-dolgunets [Flax]. Moscow-Leningrad, 1923 (in Russ.).

8. P is a rev V.E. V sbornike: Teoreticheskie osnovy selektsii rastenii [In: Theoretical basis for plant breeding]. Moscow-Leningrad, 1937, 5: 503-544 (in Russ.).

9. D e H a a n H. Flax breeding and flax varieties in the Netherlands. Euphytica, 1952, 1: 212-218.

10. Fou illo ux G. Breeding flax methods. In: Flax: Breeding and Utilisation. G. Marshall (ed.). Kluwer Academic Publishers, Dordrecht/Boston/London, 1988: 14-25.

11. S a l a s G., F ri e d t W. Comparison of pedigree selection and single seed descent for oil yield in linseed (Linum usitatissimum L). Euphytica, 1995, 83: 25-32.

12. P a v lova L.N. V sbornike: Nauchnye dostizheniya - l'novodstvu [In: Scientific advances for flax cultivation]. Tver', 2010: 39-45 (in Russ.).

13. Tekhnicheskie kul'tury /Pod redaktsiei Ya.V. Gubanova [Industrial crops. Ya.V. Gubanov (ed.)]. Moscow, 1986 (in Russ.).

14. Kvavadze E., Bar-Yosef O., Belfer-Cohen A., Boaretto E., Jakeli N., Matskievich Z., Meshveliani T. 30,000 year-old wild flax fibers. Science, 2009, 325(5946): 1359 (doi: 10.1126/science.1175404).

15. $\mathrm{P}$ a ve $1 \mathrm{e} \mathrm{k} \mathrm{M}$. Status of the Czech national flax collection and management of the International Flax Data Base within the framework of the FAO/ESCORENA Flax and other Bast Plants Network. Flax Genetic resources in Europe, 2001: 25-31.

16. Rozhmina T.A., Zhuchenko A.A. (ml.), Ushchapovski I.V., Kurchakova L.N., B a s k k ov V.A., K i s e leva T.S. Selektsiya, semenovodstvo, agrotekhnika, ekonomika i pervichnaya obrabotka l'na-dolguntsa (nauchnye trudy VNIIL, Torzhok), 2002, 1(30): 72-82 (in Russ.).

17. Diede richsen A., Richards K. Cultivated flax and the genus Linum L. In: The genus Linum. London-NY, 2003: 44.

18. Zhuchenko A.A., Rozhmina T.A., Ponazhev V.P., Pavlova L.N., Tikhomi rova V.Ya., Sorokina O.Yu., Pavlov E.I., Pozdnyakov B.A., Usanova Z.I., B ra ch N.B. Ekologo-geneticheskie osnovy selektsii l'na-dolguntsa [Eco-genetic basis for flax breeding]. Tver', 2009 (in Russ.). 
19. Len Belarusi /Pod redaktsiei I.A. Goluba [Flax in Belarus. I.A. Golub (ed.)]. Minsk, 2003 (in Russ.).

20. Ush chapovski i I.V. V sbornike: Sostoyanie $i$ perspektivy razvitiya l'novodstva $v$ Sibiri [In: Flax cultivation in Siberia - achievements and outlook]. Tomsk, 2007: 11-15 (in Russ.).

21. Khamutovski i P.R., Khamutovskaya E.M., B a lashenko D.V. V sbornike: L'novodstvo: realii i perspektivy [In: Flax cultivation - realities and prospects]. Mogilev, 2013: 40-43 (in Russ.).

22. P a v lova L.N. V sbornike: Mashinno-tekhnologicheskaya modernizatsiya l'nyanogo agropromyshlennogo kompleksa na innovatsionnoi osnove [In: Technical and technological modernization of flax agroindustry]. Tver', 2014: 29-29 (in Russ.).

23. Ush chapovski i I.V., Le me sh V.A., B ogd a nova M.V. Materialy Mezhdunarodnoi nauchno-prakticheskoi konerentsii FGBNU VNIIML «Innovatsionnye razrabotki dlya proizvodstva l'na» [Proc. Int. Conf. «Innovations for flax agroindustry]. Tver', 2015: 42-45 (in Russ.).

24. Loginov M.I., Kaban ets V.M., S it nik V.P. V sbornike: Nauchnye dostizheniya l'novodstvu [In: Scientific advances for flax cultivation]. Tver', 2010: 57-63 (in Russ.).

25. Kubrak S.V., K h ot y leva L.V. V sbornike: L'novodstvo: realii i perspektivy [In: Flax cultivation - realities and prospects]. Mogilev, 2013: 85-88 (in Russ.).

26. U sh ch a p ovski i I.V., Z h u c he n k o A.A. (ml.). V sbornike: Rol' l'na v uluchshenii sredy obitaniya $i$ aktivnom dolgoletii cheloveka [In: The role of flax in the habitat improving and active human longevity]. Tver', 2012: 19-26 (in Russ.).

27. $\mathrm{Zhu} \mathrm{ch}$ e $\mathrm{n}$ o A.A., R o z h m in a T.A. Mobilizatsiya geneticheskikh resursov l'na [Mobilization of flax genetic resources]. Moscow, 2000 (in Russ.).

28. B r a ch N.B., Kutu zova S.N., P o rok hovi nova E.A. V sbornike: Problemy povysheniya tekhnologicheskogo kachestva l'na-dolguntsa [In: Improving for technological traits in flax]. Torzhok, 2005: 96-102 (in Russ.).

29. Kutuzova S.N., Brach N.B., Porokhovinova E.A., Pavlov A.V., Shar o v I.Ya. V sbornike: Nauchnye dostizheniya - l'novodstvu [In: Scientific advances for flax cultivation]. Tver', 2010: 28-35 (in Russ.).

30. Kutuzova S.N., Brach N.B., Porokhovinova E.A., Sharov I.Ya., Pavlov A.V. V sbornike: Problemy povysheniya tekhnologicheskogo kachestva l'na-dolguntsa [In: Improving for technological traits in flax]. Torzhok, 2005: 40-48 (in Russ.).

31. D i ed e richsen A., Kusters P.M., Ke s s ler D., Ba i nas Z., Gugel R.K. Assembling a core collection from the flax world collection maintained by Plant Gene Resources of Canada. Genet. Resour. Crop Evol., 2013, 60(4): 1479-1485 (doi: 10.1007/s10722-012-9936-1).

32. Ivanova E.V., M a s li nsk y a M.E., Andronik E.L. V sbornike: L'novodstvo: realii $i$ perspektivy [In: Flax cultivation - realities and prospects]. Mogilev, 2013: 47-51 (in Russ.).

33. Soto-Cerda B.J., Duguid S.D., B o oker H.M., Rowland G.G., Di ed e r i chse n A., Cloutie r S. Association mapping of seed quality traits using the flax (Linum usitatissimum L.) core collection. Theoretical and Applied Genetics (TAG), 2014, 127(4): 881-896 (doi: 10.1007/s00122-014-2264-4).

34. Le m e s h V.A. Doklady Natsional'noi akademii nauk Belarusi, 2007, 51(6): 78-81 (in Russ.).

35. Lemesh V.A., B ogd a nova M.V., Guzenko E.V., Grushetskaya Z.E., S a $\mathrm{m}$ at ad z e T.E., Ra ch i n s k y a O.A., Murave n k o O.V. Molekulyarnaya i prikladnaya genetika, 2013,15: 75-86 (in Russ.).

36. B a č e 1 is K. Experimental mutagenesis in fiber flax breeding. Biologija, 2001, 1: 40-43.

37. Loginov M.I., Kandyba N.N., Loginov A.M. V sbornike: Problemy povysheniya tekhnologicheskogo kachestva l'na-dolguntsa [In: Improving for technological traits in flax]. Torzhok, 2005: 116-122 (in Russ.).

38. U sh chapovski i I.V., D o u rle i n I., Yakobse $\mathrm{n}$ E. V sbornike: Itogi $i$ perspektivy razvitiya selektsii, semenovodstva, sovershenstvovaniya tekhnologii vozdelyvaniya i pervichnoi pererabotki l'na-dolguntsa [In: Achievements and challenges in flax breeding, seed production, cultivation and processing]. Torzhok, 2000: 58-60 (in Russ.).

39. U s h c h a p o v s ki i I.V. V sbornike: L'novodstvo: realii i perspektivy [In: Flax cultivation - realities and prospects]. Mogilev, 2013: 347-360 (in Russ.).

40. R o w l a nd G.G. An EMS-induced low-linolenic-acid mutant in McGregor flax (Linum usitatissimum L.). Can. J. Plant Sci., 1991, 71(2): 393-396.

41. G r e e $\mathrm{n}$ A.G., M a r s h a 11 D.R. Isolation of induced mutants in linseed (Linum usitatissimum) having reduced linolenic acid content. Euphytica, 1984, 33(2): 321-328 (doi: 10.1007/BF00021128).

42. To n net M.L., Gre e n A.G. Characterization of the seed and leaf lipids of high and low linolenic acid flax genotypes. Arch. Biochem. Biophys., 1987, 252(2): 646-654 (doi: 10.1016/0003-9861(87)90070-1).

43. L y a k h V.A., S o r o k a A.I. Botanicheskie i tsitogeneticheskie osobennosti vidov roda Linum L. $i$ biotekhnologicheskie puti raboty s nimi [Botanical and cytogenetic features of species in the genus Linum L. and biotechnological methodology]. Zaporozh'e, 2008 (in Russ.).

44. B o g d a n o v a M.V. Molekulyarno-geneticheskii polimorfizm sortov $i$ landras l'na posevnogo ( $L i$ num usitatissimum L.). Avtoreferat kandidatskoi dissertatsii [Molecular-genetic polymorphism in flax (Linum usitatissimum L.) varieties and landraces. PhD Thesis]. Minsk, 2014 (in Russ.). 
45. Dietrich K. Uber die Kulturen von Embryonenausserhalb des Samens. Flora, 1924, 17: 379-417.

46. Laibach F. Das Taubwerden von Bastardsamen und die Kunstliche aufzucht von fruh absterbenden Bastardembryonen. Z. Bot., 1925, 17: 417-459.

47. Li n k G.K., Eg g e r s V. Mode, site and time of initiation of hypocotyledonary bud primordial in Linum usitatissimum L. Bot. Gaz., 1946, 107(4): 441-454.

48. I b r a h i m R.K. Media for growth of flax tissue culture. Can. J. Bot., 1971, 49(2): 295-298.

49. Li a u S., I b r a h i m R.K. Biochemical differentiation in flax tissue culture - phenolic compounds. Can. J. Bot., 1973, 51(4): 820-823.

50. G a mborg O.L., Shyluk J.P. Tissue culture, protoplasts and morphogenesis in flax. Bot. Gaz., 1976, 137(4): 301-306.

51. Pretova A., Williams E.G. Direct somatic embryogenesis from immature zygotic embryos of flax (Linum usitatissimum L.). Plant Physiol., 1986, 126(2-3): 155-161 (doi: 10.1016/S0176-1617(86)80016-5).

52. Cun ha A., F e r re i r a M.F. Somatic embryogenesis, organogenesis and callus growth kinetics of flax. Plant Cell Tiss. Organ Cult., 1996, 47(1): 1-8 (doi: 10.1007/BF02318959).

53. Li ng H.Q., B ind ing H. Improvement of plant regeneration from Linum protoplasts by the induction of somatic embryogenesis. J. Plant. Physiol., 1992, 139(4): 422-426 (doi: 10.1016/S0176-1617(11)80488-8).

54. Cunha A., Ferre ira M.F. Differences in free sterols content and composition associated with somatic embryogenesis, shoot organogenesis and calli growth of flax. Plant Sci., 1997, 124(1): 97-105 (doi: 10.1016/S0168-9452(97)04587-1).

55. J a nowicz J., Niemann J., Wojciechowski A. The effect of growth regulators on the regeneration ability of flax (Linum usitatissimum L.) hypocotyl explants in in vitro culture. BioTechnologia, 2012, 93(2): 135-138 (doi: 10.5114/bta.2012.46578).

56. Rutkowska-Krause I., Mankowska G., Lukaszewicz M., Szopa J. Regeneration of flax (Linum usitatissimum L.) plants from anther culture and somatic tissue with increased resistance to Fusarium oxysporum. Plant Cell Rep., 2003, 22(2): 110-116 (doi: 10.1007/s00299-003-0662-1).

57. B o n e 11 M.L., La s a g a S.L. Genetic analysis of the response of linseed (Linum usitatissimum L.) somatic tissue to in vitro cultivation. Euphytica, 2002, 125(3): 367-372 (doi: 10.1023/A:1016013609068).

58. S u n H., Fu W. Induction of pollen plants in flax (Linum usitatissimum L.) and preliminary observations on performance of their progenies. Acta Genet. Sin., 1981, 8(4): 369-374.

59. P o ly a k o v A.V. Biotekhnologiya $v$ selektsii l'na [Biotechnological techniques in flax breeding]. Tver', 2000 (in Russ.).

60. $\mathrm{Nichterlein} \mathrm{K.,} \mathrm{U} \mathrm{mba} \mathrm{ch} \mathrm{H.,} \mathrm{Friedt} \mathrm{W.} \mathrm{Investigation} \mathrm{on} \mathrm{androgenesis} \mathrm{in} \mathrm{breeding} \mathrm{of}$ linseed (Linum usitatissimum L.). Vortr. Pflanzenzuchtg, 1989, 15(1): 13-25.

61. Prolet ov a N.V. V sbornike: Nauchnye dostizheniya - l'novodstvu l'novodstvu [In: Scientific advances for flax cultivation]. Tver', 2010: 136-144 (in Russ.).

62. Prolet ova N.V., Los hakova N.I., P oly a k ov A.V. Poluchenie rastenii-regenerantov l'na-dolguntsa, ustoichivykh $k$ fuzarioznomu uvyadaniyu, metodami in vitro (kul'tura pyl'nikov, kletochnaya selektsiya): Metodicheskie rekomendatsii [Regeneration of fusariosis-resistant flax plants from anther culture and after cell selection]. Torzhok, 2008 (in Russ.).

63. Ush cha povski i I.V., Vi nog radova E.G., K a o T.A., Ngue n T.M.Kh. V sbornike: Problemy povysheniya tekhnologicheskogo kachestva l'na-dolguntsa [In: Improving for technological traits in flax]. Torzhok, 2005: 123-130 (in Russ.).

64. Vi n o g r a o va E.G. V sbornike: Nauchnye dostizheniya - l'novodstvu [In: Scientific advances for flax cultivation]. Torzhok, 2010: 147-150 (in Russ.).

65. B a si ran N., A r m it a g e P., S c ot t R.J., D raper J. Genetic transformation of flax (Linum usitatissimum) by Agrobacterium tumefaciens: regeneration of transformed shoots via a callus phase. Plant Cell Rep., 1987, 6(5): 396-399 (doi: 10.1007/BF00269571).

66. Z h a n X.C., J o n e s D.A., K e r r A. Regeneration of flax plants transformed by Agrobacterium rhizogenes. Plant Mol. Biol., 1988, 11(5): 551-559 (doi: 10.1007/BF00017455).

67. J o rda n M.C., M c H u g h e n A. Glyphosate tolerant flax plants from Agrobacterium mediated gene transfer. Plant Cell Rep., 1988, 7(4): 281-284 (doi: 10.1007/BF00272543).

68. $\mathrm{M} \mathrm{c} \mathrm{Hughen} \mathrm{A.} \mathrm{Agrobacterium} \mathrm{mediated} \mathrm{transfer} \mathrm{of} \mathrm{chlorsulfuron} \mathrm{resistance} \mathrm{to} \mathrm{commercial}$ flax cultivars. Plant Cell Rep., 1989, 8(8): 445-449 (doi: 10.1007/BF00269045).

69. $\mathrm{McHughen} \mathrm{A.,} \mathrm{Holm} \mathrm{F.} \mathrm{Herbicide} \mathrm{resistant} \mathrm{transgenic} \mathrm{flax} \mathrm{field} \mathrm{test} \mathrm{-} \mathrm{agronomic} \mathrm{per-}$ formance in normal and sulfonylurea containing soils. Euphytica, 1991, 55(1): 49-56 (doi: 10.1007/BF00022559).

70. M c Sheffrey S.A., M c Hughe n A., Devine M.D. Characterization of transgenic sulfonylurea-resistant flax (Linum usitatissimum). Theor. Appl. Genet., 1992, 84(3): 480-486 (doi: 10.1007/BF00229510).

71. McHughen A., Holm F. Development and preliminary field testing of a glufosinateammonium tolerant transgenic flax. Can. J. Plant Sci., 1995, 75(1): 117-120.

72. Wrobel-Kwiatkowska M., Lorenc-Kukuła K., Starzycki M., Oszmianski J., Kepczynska E., S z o p a J. Expression of B-1,3-glucanase in flax causes increased resistance to fungi. Physiol. Mol. Plant Pathol., 2004, 65(5): 245-256 (doi: 10.1016/j.pmpp.2005.02.008). 
73. Marshall G., Courduries P. Somaclonal variation in Linum usitatissimum L. Proc. European Regional Workshop on Flax «Flax as a fibre and oil bearing crop». Brno, Czechoslovakia, 1991: 143-154.

74. M c H ugh e $\mathrm{n} \mathrm{A.,} \mathrm{Swartz} \mathrm{M.} \mathrm{A} \mathrm{tissue} \mathrm{culture} \mathrm{derived} \mathrm{salttolerant} \mathrm{line} \mathrm{of} \mathrm{flax} \mathrm{(Linum} \mathrm{usita-}$ tissimum). J. Plant Physiol., 1984, 117(2): 109-117 (doi: 10.1016/S0176-1617(84)80023-1).

75. O'Connor B.J., Roberts on A.J., Gust a L.V. Differential stress tolerance and cross adaptation in a somaclonal variant of flax. J. Plant Physiol., 1991, 139(1): 32-36 (doi: 10.1016/S0176-1617(11)80160-4).

76. J o r d a n M.C., M c H u g h e $\mathrm{n}$ A. Selection of chlorsulfuron resistance in flax (Linum usitatissimum) cell cultures. J. Plant Physiol., 1987, 131(3-4): 333-338 (doi: 10.1016/S01761617(87)80172-4).

77. Guze n k o E.V., L e m e s h V.A., B o g d a n ov a M.V. Molekulyarnaya i prikladnaya geneti$k a, 2012,13:$ 7-18 (in Russ.).

78. Rachinskay a O.A., Le mesh V.A., Muravenko O.V., Yurkevich O.Yu., Gu zenko E.V., Bol'sheva N.L., Bogd a nova M.V., S a matadze T.E., Popov K.V., Malyshev S.V., Shostak N.G., Xe 11 e r K., Khotyleva L.V., Z e len in A.V. Genetika, 2011, 47(1): 65-75 (in Russ.).

79. Yure n k v a S.I., K h o t y le va L.V. V sbornike: Itogi i perspektivy razvitiya selektsii, semenovodstva, sovershenstvovaniya tekhnologii vozdelyvaniya i pervichnoi pererabotki l'na-dolguntsa [In: Achievements and challenges in flax breeding, seed production, cultivation and processing]. Torzhok, 2000: 48-4 (in Russ.).

80. Fu Y.B., Rowland G.G., Duguid S.D., Ri c hards K.W. RAPD analysis of 54 North American flax cultivars. Crop Science, 2003, 43(4): 1510-1515 (doi: 10.2135/cropsci2003.1510).

81. Le mesh V.A., B ogdanova M.V., K hotyleva L.V. Doklady NAN Belarusi, 2006, 50(2): 51-54 (in Russ.).

82. Truksa M., MacKenzie S.L., Qiu X. Molecular analysis of flax 2S storage protein conlinin and seed specific activity of its promoter. Plant Physiol. Biochem., 2003, 41(2): 141-147 (doi: 10.1016/S0981-9428(02)00022-0).

83. Venglat P., Xiang D., Qiu S., Stone S.L., Tibiche C., Cram D., AltingMees M., Nowak J., Cloutier S., Deyholos M., Bekkaoui F., Sharpe A., W a ng E., Row land G., S e lvaraj G., D a t l a R. Gene expression analysis of flax seed development. BMC Plant Biol., 2011, 11: 74 (doi: 10.1186/1471-2229-11-74).

84. Kutuzova S.N., Gavrilyuk I.P., Eggi E.E. Trudy po prikladnoi botanike, genetike $i$ selektsii, 1999, 156: 29-39 (in Russ.).

85. Evtimova M., Vlahova M., Atanassov A. Flax improvement by biotechnology means. Journal of Natural Fibers, 2005, 2(2):

86. S a m m o u r R.H. Proteins of linseed (Linum usitatissimum L.), extraction and characterization by electrophoresis. Botanical Bulletin of Academia Sinica, 1999, 40: 121-126.

87. Mansby E., Díaz O., Von B oth mer R. Preliminary study of genetic diversity in Swedish flax (Linum usitatissimum). Genet. Resour. Crop Evol., 2000, 47: 417-424 (doi: 10.1023/A:1008721528588).

88. R a y C. Cytological studies on the flax genus (Linum). Am. J. Bot., 1944, 31: 241-248.

89. L e w i s W.H. A hexaploid Linum (Lineceaceae) from eastern Ethiopia. Sida, 1964, 1: 383-384.

90. Ha r r is B.D. Chromosome numbers and evolution in North American species of Linum. Am. J. Bot., 1968, 55(10): 1197-1204.

91. Ch e n n ve e ra i a h M.S., J o sh i K.K. Karyotypes in cultivated and wild species of Linum. Cytologia, 1983, 48: 833-841.

92. Muravenko O.V., Amosova A.V., Samatadze T.E., Popov K.V., Zelenin A.V. Genetika, 2001, 37(3): 332-335 (in Russ.).

93. Culli s C.A. Mechanisms and control of rapid genomic changes in flax. Annals Bot., 2005, 95(1): 201-206 (doi: 10.1093/aob/mci013).

94. Goldsbrough P.B., E 11 is T.H.N., Cull is C.A. Organization of the 5S RNA genes in flax. Nucl. Acids Res., 1981, 9(22): 5895-5904.

95. S c hne eberger R.G., Cre is se n G.P., Cullis C.A. Chromosomal and molecular analysis of 5S RNA gene organization in the flax, Linum usitatissimum. Gene, 1989, 83(1): 75-84 (doi: 10.1016/0378-1119(89)90405-8).

96. Pruitt R.E., M a y row itz E.M. Characterization of the genome of Arabidopsis thaliana. J. Mol. Biol., 1986, 187(2): 169-183 (doi: 10.1016/0022-2836(86)90226-3).

97. Ev a n s G.C. The Quantitative analysis of plant growth. Oxford, 1972.

98. Wang Z., Hobson N., Galindo L., Zhu S., Shi D., McDill J., Yang L., Hawkins S., Neutelings G., Datla R., Lambert G., Galbraith D.W., Grassa C.J., Geraldes A., C ronk Q.C., Cullis C., Dash P.K., Kumar P.A., Cloutie r S., Sharpe A.G., Wong G.K., Wang J., D e yholos M.K. The genome of flax (Linum usitatissimum) assembled de novo from short shotgun sequence reads. The Plant Journal, 2012, 72(3): 461-473 (doi: 10.1111/j.1365-313X.2012.05093.x).

99. Y o u F.M., Ku ma r S., B a nik M., Clou t i e r S. Ordering draft genome sequence of flax (Linum usitatissimum). Plant and Animal Genome XXI Conference. San Diego, 2013. Available 
https://pag.confex.com/pag/xxi/webprogram/Paper4988.html. Accessed September 5, 2013.

100. Cloutier S., Ragupathy R., Niu Z., Duguid S. SSR-based linkage map of flax (Linum usitatissimum L.) and mapping of QTLs underlying fatty acid composition traits. Mol. Breed., 2011, 13(4): 437-451 (doi: 10.1007/s11032-010-9494-1).

101. Ragupathy R., Rathinavelu R., Cloutier S. Physical mapping and BAC-end sequence analysis provide initial insights into the flax (Linum usitatissimum L.) genome. $B M C G e-$ nomics, 12: 217 (doi: 10.1186/1471-2164-12-217).

102. Cloutier S., Miranda E., Ward K., Radovanovic N., Reimer E., Walichnowski A., Datla R., Rowland G., Duguid S., Ragupathy R. Simple sequence repeat marker development from bacterial artificial chromosome end sequences and expressed sequence tags of flax (Linum usitatissimum L.). Theor. Appl. Genet., 2012, 13(4): 685-694 (doi: 10.1007/s00122-012-1860-4).

103. F u Y.B. Geographic patterns of RAPD variation in cultivated flax. Crop Sci., 2005, 45(3): 1084-1089 (doi: 10.2135 /cropsci2004.0345).

104. Vromans J. Molecular genetic studies in flax (Linum usitatissimum L.). PhD thesis. Wageningen University, The Netherlands, 2006.

105. Z o h a r y D., H o p f M. Domestication of plants in the Old World: the origin and spread of cultivated plants in West Asia, Europe and the Nile Valley. Oxford University Press, Oxford, 2000.

106. Varshney R.K., Glaszmann J.C., Leung H., Ribaut J.M. More genomic resources for less-studied crops. Trends. Biotechnol., 2010, 28(9): 452-460 (doi: 10.1016/j.tibtech.2010.06.007).

107. Dho laki a B.B., A m miraju J.S., S a nt ra D.K., S ingh H., K a t ti M.V., Lagu M.D., T a m hankar S.A., Rao V.S., Gupta V.S., Dhaliwal H.S., Ranjekar P.K. Molecular marker analysis of protein content using PCR-based markers in wheat. Biochem. Genet., 2001, 39(9-10): 325-338.

108. Thiel T., Michalek W., Varshney R., Graner A. Exploiting EST databases for the development and characterization of gene-derived SSR-markers in barley (Hordeum vulgare L.). Theor. Appl. Genet., 2003, 106(3): 411-422 (doi: 10.1007/s00122-002-1031-0).

109. Tian A.G., Wang J., Cui P., Han Y.J., Xu H., Cong L.J., Huang X.G., W a ng X.L., Ji a o Y.Z., W a ng B.J., W ang Y.J., Zh ang J.S., C he n S.Y. Characterization of soybean genomic features by analysis of its expressed sequence tags. Theor. Appl. Genet., 2004, 108(5): 903-913 (doi: 10.1007/s00122-003-1499-2).

110. $\mathrm{Yu}$ J., B e r nardo R. Changes in genetic variance during advanced cycle breeding in maize. Crop Sci., 2004, 44(2): 405-410 (doi: 10.2135/cropsci2004.4050).

111. Go ng Y.M., Xu S.C., M a o W.H., H u Q.Z., Zhang G.W., Ding J., Li Y.D. Developing new SSR markers from ESTs of pea (Pisum sativum L.). J. Zhejiang Univ. Sci. B., 2010, 11(9): $702-707$ (doi: 10.1631/jzus.B1000004).

112. Yu J., Dixit A., Ma K.H., Chung J.W., Park Y.J. A study on relative abundance, composition and length variation of microsatellites in 18 underutilized crop species. Genet. Resour. Crop. Evol., 2006, 56(2): 237-246 (doi: 10.1007/s10722-008-9359-1).

113. Eujayl I., S orrells M., B a um M., Wolters P., Powell W. Assessment of genotypic variation among cultivated durum wheat based on EST-SSRs and genomic SSRs. Euphytica, 2001, 119(1-2): 39-43 (doi: 10.1023/A:1017537720475).

114. Han Z.G., Guo W.Z., S ong X.L., Z h ang T.Z. Genetic mapping of EST-derived microsatellites from the diploid Gossypium arboretum in allotetraploid cotton. Mol. Genet. Genomics, 2004, 272(3): 308-327 (doi: 10.1007/s00438-004-1059-8).

115. Hisano H., Sato S., Is obe S., Sasamoto S., Wada T., Matsuno A., Fujishiro T., Yamada M., Nakayama S., Nakamura Y., Watanabe S., $\mathrm{Harad}$ a K., Tabat a S. Characterization of the soybean genome using EST-derived microsatellite markers. DNA Res., 2007, 14(6): 271-281 (doi: 10.1093/dnares/dsm025).

116. Lemesh V.A., Bogdanova M.V., Semashko T.V., Beinya V.A., Kil'chevskii A.V., K hotyle va L.V. Doklady NAN Belarusi, 2013, 57(2): $74-78$ (in Russ.).

117. Le mesh V.A., Bogdanova M.V., K Hotyleva L.V. Doklady NAN Belarusi, 2012, 56(4): 77-82 (in Russ.). 